\title{
IN VITRO AND IN VIVO EFFICIENCY OF EUPHORBIA ANTIQUORUM AS ANTIOXIDANT AND HEPATOPROTECTIVE AGAINST CCL4- HEPATIC HAZARDS IN RATS.
}

\author{
Mansour Hamed Gait \\ Manger of Applied Research of Medicinal Plants (ARCMP) and Head of antibiotic Department \\ National Organization for Drug Control and Research (NODCAR)
}

\begin{abstract}
The aqueous extract of the aerial parts of Euphorbia antiquorum (EA) Linn was evaluated for its in vitro antioxidant efficiency as well as in vivo hepatoprotective and antioxidant activity to validate its use in traditional therapeutic medications. The activity of different doses of EA extract ( at $20 \mathrm{ug}, 40 \mathrm{ug}, 6 \mathrm{o} \mathrm{ug}, 8 \mathrm{o} \mathrm{ug}$ and $100 \mathrm{ug} / \mathrm{ml}$ ) exerted in vitro significant antioxidant activity as it caused reducing power, hydroxyl and superoxide anion radical scavenging activities and inhibition properties. The in vivo study was performed on 50 male and female albino rats from the animal house of National Organization for Drug Control and Research (NODCAR) weighing 150 - 250 grams. Normal animals were employed simultaneously with experimental groups. Rats were divided equally into five groups ( $\left.\mathrm{G}_{1}\right)$ rats received saline as a normal for 4 weeks , (G 2) rats received orally $\mathrm{CCl}_{4}$ and were served as intoxicated control for 4 weeks, $\left(\mathrm{G}_{3}\right)$ rats received both $\mathrm{CCl}_{4}$ and silymarin as a reference agent for 4 weeks ,(G4) rats received both $\mathrm{CCl}_{4}$ and $\mathrm{EA}\left(125 \mathrm{mg} / \mathrm{kg}\right.$ b.w) for 4 weeks and $\left(\mathrm{G}_{5}\right)$ received both $\mathrm{CCl}_{4}$ and EA $(250 \mathrm{mg} / \mathrm{kg} \mathrm{b.w})$ for 4 weeks. It may be pointed out in the current study that antioxidant efficacy was reinforced by a significant hepatoprotection of EA (at $125 \mathrm{mg}$ and $250 \mathrm{mg} / \mathrm{kg} \mathrm{b.w)} \mathrm{displayed} \mathrm{by} \mathrm{decreasing} \mathrm{the} \mathrm{serum} \mathrm{levels} \mathrm{of} \mathrm{alanine} \mathrm{Transferase} \mathrm{(}$ ALT), aspartate transferase (AST), alkaline phosphatase (ALP) , as well as bilirubin (total, conjugated and unconjugated), cholesterol, triglycerides (T.G), Total proteins (T.P), albumin ( $\mathrm{Alb}$ ) and carbonyl protein (PC) after treated with carbon tetrachloride $\left(\mathrm{CCl}_{4}\right)$, the two extracts also significantly increased lipid peroxidation (malondialdhyde MAD) levels of tissue in a dose dependant manner and increased superoxide anion radical (SOD), glutathione (GSH), glutathione peroxide (GPX), glutathione transferase (GST) levels. The antioxidant and hepatoprotective activities of the two test extracts where assessed in vivo and in vitro where either of the two test extracts or silymarin exhibited marked hepatoprotection against the toxic dose of CCL4. The results obtained pointed out that EA could be a potential source of natural antioxidant and hepatoprotection.
\end{abstract}

\section{INTRODUCTION}

Several herbs and herbal products are known to possess antioxidant principles and may be useful as hepatoprotective agents (Fauconneau, et al., 1997; Sunitha et al., 2001, and Saleem et al., 2010). Herbs belonging to Euphorbiaceae were reported to have antioxidant principles like flavonoids and shown hepatoprotective properties (Trease and Evans, 2001 and Lanthers et al., 1991). Euphorbia antiquorum is a large shrub or small tree growing throughout the hotter parts of 
the world. The juice of the plant is acrid, anti inflammatory, purgative and is useful in rheumatic diseases, dropsy, gout, neuropathy, deafness, cough (Kirtikar and Basu, 1975). The juice, which flows from the branches, is a popular application to wart and other cutaneous affections (Vaidyaratnam and Vaidyasala, 1995). Isolated compounds from the plant include euphol, antiquol, euphorbol, isohelinol, camelliol (Akihisa et al., 2005). Preliminary photochemical investigation showed the presence of triterpenes and flavonoids, both of which are reported to possess hepatoprotective and antioxidant activity (Sunitha et al., 2001). Since, liver is a very vital system involved in the body metabolic activities, chemical reactions in the liver may generate several reactive species like free radicals. These reactive species form covalent bond with the lipid of the tissue. In that respect, carbon tetrachloride $(\mathrm{CCl} 4)$ is one of such hazardous chemical which induces hepatopathy through membrane lipid peroxidation by its free radical derivative, $(\mathrm{CCl} 3$, $\left.\mathrm{CCl} 32_{2}^{\circ}\right)$. Excessive production of the reactive species manifests in tissue thiol depletion, lipid peroxidation, plasma membrane damage etc., culminating into severe hepatic injury (Chrungoo et al., 1997). It may be pointed out that pharmacological profile of the plant is not completely established. Therefore, the present study was designed with an aim to assess the antioxidant and hepatoprotective activity of aerial parts of Euphorbia antiquorum Linn. (EA), against carbon tetrachloride CCl4 induced liver hazards.

\section{MATERIALS AND METHODS}

1-Chemicals: all chemicals were of analytical grade and purchased from Sigma -Aldrich Chemicals Co. (St.Louis ,MO,USA)

2-Plant material and extract preparation: Aerial parts of Euphorbia antiquorum (EA ) were shredded dried, ground to coarse powder and subjected to successive extraction by using three different solvents in an increasing order of their polarity (pet. ether, $\mathrm{CHCl} 3$ and methanol) in soxhlet apparatus, until the eluent became colorless and then macerated with chloroform: water (3 $: 1)$. The chloroform layer was dried under reduced pressure. In the meantime, the aqueous layer extracted was then dried under reduced pressure at a yield of $15 \%(w / w)$. From this extract, on evaporation of water in vacuum, a brown colored substance was obtained which was kept at $4^{0} \mathrm{C}$ until use.

Both extract layers were subjected to the following preliminary photochemical tests (quality control methods), These tests included FCl3, TLC, GLC and UV (Merill, 1977).

All the tests reveal that the plant posses steroids, glycosides, triterpenoids, tannins and flavonoids. Since aqueous extract has polyphenolic compounds and triterpenoids, this extract was selected for further study.

\section{3 -Experimental Design}

\section{1- In vitro study}

2.1.1 Total phenolic contents: The total phenolic contents of the tested extracts were determined by Folin Ciocalteau reagent in alkaline medium according to the method of Macdonlad $\boldsymbol{e t}$ al. (2001) with slight modification. The results expressed as ug gallic acid equivalent (GAC) per $\mathrm{mg}$ dry extract (standard gallic acid curve equation $\mathrm{Y}=0.0063 \mathrm{x}, \mathrm{R}^{2}=0.9996$ )

3.1.2-Total flavonoids content: The total flavonoids content was determined according to aluminum chloride colorimetric method as described by Zou et al., (2004). The result expressed 
as ug rutin equivalent $(\mathrm{RE})$ per $\mathrm{mg}$ dry extract (standard rutin curve equation $\mathrm{Y}=0.0119 \mathrm{x}$, $\left.\mathrm{R}^{2}=0.9996\right)$

\subsection{3-Assessment of superoxide-anion scavenging activity:}

Measurement of superoxide anion scavenging activity was done based on the method described by Nishimiki et al. (1972) and slightly modified. The reaction mixture was incubated at $25^{\circ} \mathrm{C}$ for 5 minutes and the absorbance at $560 \mathrm{~nm}$ was measured against blank samples.

\subsection{4-Assessment of $\mathrm{OH}$ radical scavenging activity in 2-DOPH system:}

Hydroxyl radical generation by phenyl hydrazine has been measured by the 2-deoxyribose degradation (Barry and John, 1981 and Jayasri et al., 2009). The reaction mixture was heated for 10 minutes, in a boiling water bath. The tubes were then cooled briefly and absorbance was measured at $532 \mathrm{~nm}$.

\subsection{5- Assessment of reducing power:}

The reducing power was determined according to the method of Oyaizu (1986), using different doses of EA (20 ug, $40 \mathrm{ug}, 60 \mathrm{ug}, 80 \mathrm{ug}$ and $100 \mathrm{ug} / \mathrm{ml})$. The absorbance of end product was measured at $700 \mathrm{~nm}$.

Radical scavenging \% =1- (Absorbance of sample / Absorbance of control) X 100.

\section{3-2 In vivo study}

3.2.1- Test animals: 50 adult male and female albino rats from the animal house of National Organization for Drug Control and Research (NODCAR) weighing 150 - 250 grams were employed.

\subsection{2 - Assessment of oral toxicity:}

Oral toxicity was conducted according to the method of Organization for Economic Cooperation and Development (OECD 1996). Five groups of six albino rats each weighing 150: 250 grams b.w was used. Animals were kept fasting providing only water after which plant extract was orally administrated by gastric tube in different gradual dose $(1-5 \mathrm{gm} / \mathrm{kg} \mathrm{b.w})$ and observed for toxic symptoms and mortality for $72 \mathrm{hrs}$. This experiment proved that non of the animals died at $5 \mathrm{gm} / \mathrm{kg} \mathrm{b.w}$. For this reason $1 / 20$ and 1/40 of this dose were selected for further in vivo study (Jyothi et al., 2007).

\subsection{3-Assessment of carbon tetra chloride (CCL4) induced toxicity:}

The method of Yick $\boldsymbol{e t}$ al., (1993) was used for screening the hepatoprotectivity of the test extract. All animals (except Group 1) were treated orally with CCI4 (11\% v/v in olive oil) at a dose of $(1 \mathrm{ml} / \mathrm{kg} \mathrm{b}$. w) for 4 weeks animals were then sacrificed $24 \mathrm{hrs,} \mathrm{after} \mathrm{the} \mathrm{last} \mathrm{dosing}$ of CCl4 treatment, hepatic tissue and heparinized blood sample were taken for assessment of the test parameters.

\subsection{4 - EA hepatoprotectivity:}

Rats were divided equally into five groups 10 in each. All rats except G1 were treated orally with $\mathrm{CCl} 4(11 \% \mathrm{v} / \mathrm{v}$ in olive oil) at a dose of $1 \mathrm{ml} / \mathrm{kg} \mathrm{b} \mathrm{w}$.). For screening the hepatoprotectivity of EA aqueous extract. The two doses of (125 \& $250 \mathrm{mg} / \mathrm{kg} \mathrm{b} . \mathrm{w})$ extract of EA were employed (Jyothi et al., 2007). Animals were sacrificed 24 hrs, after the last dose of 
CCl4 treatment; hepatic tissue and heparinized blood sample were taken for assessment of the test parameters.

Group I: ten male and female albino rats received saline orally $(1 \mathrm{ml} / \mathrm{kg})$ as a normal for 4 weeks. Group II: ten male and female albino rats received orally CCl4 $(1 \mathrm{ml} / \mathrm{kg} \mathrm{b.w})$ as intoxicated control for 4 weeks. Group III: ten male and female albino rats received orally both CCl4 (1 ml/kg b.w) and silymarin (25 mg/kg b.w) as a reference drug for 4 weeks. Group IV: ten male and female albino rats received orally both CCl4 (1 ml/kg b.w) and EA (125 mg/kg b.w) as a treated group for 4 weeks .Group V: ten male and female albino rats received orally both CCl4 and EA (250 mg/kg b.w) as a treated group for 4 weeks.

\subsection{5-Blood, Serum, liver tissue samples and test parameters:}

Blood samples were collected from the retrorbital plexus veins using heparinized micro tubes just before scarification and liver excision. Blood samples were centrifuged at $1500 \mathrm{rpm}$ for 15 minutes. Sera were separated and liver tissues were kept at $-2^{0} \mathrm{C}$ until the time of determination of the following biochemical parameters:-

\subsection{6 -Serum Samples:-}

Serum total cholesterol according to method of Allain et al. (1974). Serum triglycerides (T.G) according to method of Fossati and Prencipe (1982). Serum aspartate transferase (AST) and alanine transferase (ALT) according to method of Retiman and Frankel (1957). Serum alkaline phosphatase (ALP) according to method of Johan and Bauer (1982). Serum bilirubin according to method of Tiez, (1968). Serum total proteins (T. P) according to method of Domus (1975). Serum Albumin (Alb) according to method of Domus et al. (1971).

\subsection{7- Liver tissues:-}

Malondialdhyde (MDA) a marker of lipid peroxidation according to method of Buege and Aust (1978). Superoxide anion radical (SOD) according to method of Marklund and Marklund (1974). Glutathione (GSH) according to method of Tietze (1986). Glutathione peroxidase (GPX) according to method of Rotruck et al. (1973) .Glutathione transferase (GST) according to method of Habig et al. (1974). Carbonyl proteins (PC) according to method of Levin et al. (1990).

\section{3-Statistical analysis:}

Data were analyzed by ANOVA followed by Bonferroni's multiple variances test. All values were reported as the mean \pm S.E (SEM). Statistical comparisons of two groups were made using student's t test by Snedicor and Cochran (1967): All statistical calculations were carried out using (SPSS) program .Values were considered as:

1 - Significant, ** High Significant and *** Very high Significant at $\mathrm{p}<0.05, \mathrm{p}<0.01$ and $<0.001$ from initial normal control.

2-a: Significant, b: High Significant and c: Very high Significant from the CCL4 corresponding group.

3-A: Significant, B: High Significant and C: Very high Significant from the CCL4 Silymarin corresponding group.

4-k: Significant, 1: High Significant and m: Very high Significant between CCL4 EA- 125 and EA 250 group. 


\section{RESULTS}

\section{1- In vitro:-}

1.1-Reducing power and $\mathrm{OH}$ radical scavenging activity:

Reducing power of EA may serve as a significant indicator of its potential antioxidant activity (Table 1). In vitro results demonstrated that the different doses of EA (20 ug, $40 \mathrm{ug}, 60$ $\mathrm{ug}, 80 \mathrm{ug}$ and $100 \mathrm{ug} / \mathrm{ml}$ ) exhibited a remarkable reducing potency to donate electron to stabilize the reactive free radical and reduce the oxidized intermediates in dose dependant as compared to reference agent of SMS (25 ug/ml) in PMS-NaOH system.

Table 1: In vitro effect of serial different doses of EA extract on the reducing power and $\mathrm{OH}$ radical scavenging activity (inhibitory effects)

\begin{tabular}{|l|c|c|c|c|c|}
\hline Item & \multicolumn{4}{|c|}{$\begin{array}{c}\text { Reducing power } \\
\text { Potency }\end{array}$} \\
\hline Treatment & $\begin{array}{c}\text { Dose by } \\
(\text { ug/ml) }\end{array}$ & $\begin{array}{c}\text { Reducing property } \\
\text { (Abs) }\end{array}$ & $\begin{array}{c}\text { Increase } \\
\text { changes } \\
\%\end{array}$ & $\begin{array}{c}\text { PMS-NaoH system - } \\
\text { (Abs) }\end{array}$ & $\begin{array}{c}\text { Inhibition } \\
\text { changes } \\
\%\end{array}$ \\
\hline Control & 9 & $0.255 \pm 0.0016$ & 0 & $0.796 \pm 0.0101$ & 0 \\
\hline SMS & 25 & $0.450 \pm 0.0104^{* * *}$ & 76 & $0.175 \pm 0.005^{* * *}$ & 89 \\
\hline EA1 & 20 & $0.325 \pm 0.0042^{\# * * *}$ & 27 & $0.586 \pm 0.004^{\# * *}$ & 27 \\
\hline EA2 & 40 & $0.345 \pm 0.0085^{\# * * *} a$ & 35 & $0.505 \pm 0.003^{\# * *} a$ & 37 \\
\hline EA3 & 60 & $0.385 \pm 0.0032^{\# * * *} a B$ & 50 & $0.415 \pm 0.002^{\# * * *} a B$ & 48 \\
\hline EA4 & 80 & $0.415 \pm 0.0012^{\# * * *} a B k$ & 62 & $0.335 \pm 0.001^{\# * * *} a B k$ & 68 \\
\hline EA5 & 100 & $0.455^{* 0.0114^{\# * * *} a B k L}$ & 78 & $0.246 \pm 0.011^{\# * * *} a B k L$ & 70 \\
\hline
\end{tabular}

*** Very high Significant at $\mathrm{p}<0.001$ from (PMS / NaoH) control.

\#: Significant from the SMS (PMS / NaoH) as reference agent.

a: Significant from the EA 20 in (PMS / NaoH).

B: H .Significant from the EA 40 in (PMS / NaoH).

$\mathrm{K}$ : Significant from the EA 6o in (PMS / NaoH).

H. Significant from the EA 8o in (PMS / NaoH).

1.2-Hydroxyl radical scavenging activity by 2-DOPH:

The data shown in (Table 2) in vitro study revealed that in the phenylhydrazine solution contained a different doses of EA (20 ug,40 ug,60 ug,80 ug and $100 \mathrm{ug} / \mathrm{ml}$ ) generated a different concentrations of $\mathrm{OH}$ radicals as $(22 \%, 40 \%, 51 \%, 64 \%$ and $71 \%$ respectively) where measured by 2- deoxyribose degradation solution system (2-DOPH) . 
Table 2 : In vitro effect of serial different doses of EA extract on $\mathrm{OH}$ radical scavenging activity calculated as ( inhibitory effects ) regarding to SMS ( reference agent), by 2deoxyribose phenyl hydrazine solution (2-DOPH).

\begin{tabular}{|l|c|c|c|}
\hline \multirow{2}{*}{ Item } & \multicolumn{3}{|c|}{ Assay (Abs 532 nm ) } \\
\hline Incubation system & $\begin{array}{c}\text { Doses by } \\
\text { (ug/ml) }\end{array}$ & Abs & $\begin{array}{c}\text { Inhibition changes } \\
\%\end{array}$ \\
\hline 2-DOPH control & 9 & $0.455 \pm 0.0034$ & 0 \\
\hline 2-DOPH / SMS & 25 & $0.070 \pm 0.00252^{* * *}$ & 85 \\
\hline 2-DOPH / EA1 & 20 & $0.355 \pm 0.0055^{* * * \#}$ & 22 \\
\hline 2-DOPH / EA2 & 40 & $0.275 \pm 0.0064^{* * *} \# a$ & 40 \\
\hline 2-DOPH / EA3 & 60 & $0.225 \pm 0.0055^{* * * \# a B}$ & 51 \\
\hline 2-DOPH /EA4 & 80 & $0.165 \pm 0.0035^{\# * * *} a B k$ & 64 \\
\hline 2-DOPH /EA5 & 100 & $0.135 \pm 0.0078^{\# * * * a B k L}$ & 71 \\
\hline
\end{tabular}

*** Very high Significant at $\mathrm{p}<0.001$ from (DOPH) as a control.

-\#: Significant from the SMS in (DOPH) as reference agent.

a: Significant from the EA 20 in (DOPH).

B: H. Significant from the EA 40 in (DOPH).

$\mathrm{K}$ : Significant from the EA 60 in (DOPH).

$L$ : H. Significant from the EA 80 in (DOPH).

\section{2- In vivo:-}

2.1 Test for oral acute toxicity in vivo study:

Oral acute toxicity test for EA extract showed no lethality or signs of toxicity up to dose level of (5 grams $/ \mathrm{kg} \mathrm{b.} \mathrm{w)} \mathrm{and} \mathrm{were} \mathrm{considered} \mathrm{as} \mathrm{safe.} \mathrm{Therefore,} \mathrm{one} \mathrm{-twentieth} \mathrm{and} \mathrm{one-}$ fortieth of the maximum dose $(125 \& 250 \mathrm{mg} / \mathrm{kg} \mathrm{b.w})$ for the test extract were selected for evaluation hepatoprotective activity.

2. 2-Hepatoprotective activities:

The data depicted in (Table 3) supported and substantiated the hepatotoxicity of the oral administration of CCL4. ( $1 \mathrm{mg} / \mathrm{kg} / \mathrm{b} . \mathrm{w})$ for 4 weeks, where very highly significant increase $(\mathrm{p}<$ 0.001) in serum enzymes, ALT, AST, ALP, as well as bilirubin (total, conjugated and unconjugated), cholesterol, triglycerides, MDA and PC respectively. Meanwhile, very high significant decrease in the T.P, SOD, GSH, GPX, GST, and Alb levels respectively; as compared to the normal control rats were indicated. The data shown (in the same table) also indicated the $\%$ 
changes recorded due to $\mathrm{CCl} 4$ intoxications after 4 weeks of experimental period. As can be seen from the table, $\mathrm{CCl} 4$ induced exaggerated $\%$ elevation in serum enzymes and total, direct \& indirect bilirubin. The recorded \% changes indicated that antioxidant levels serum total protein, albumin and total cholesterol were less prominent.

Table 3: In vivo disorder indicated in the test biochemical parameters after 4 weeks oral CCl4 induced hepatotoxicity in rats.

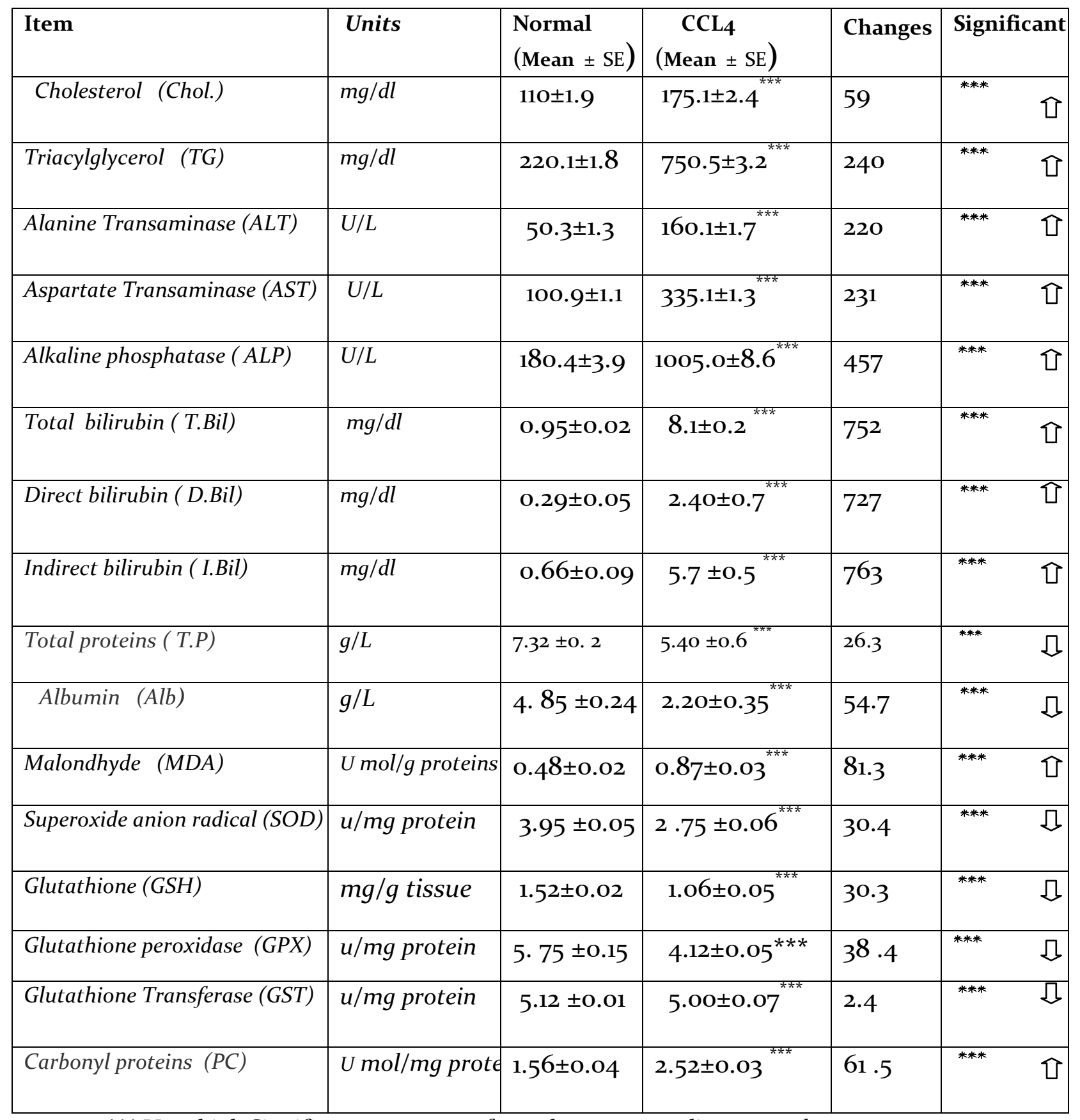

${ }^{* * *}$ Very high Significant at $p<0.001$ from the corresponding control. 
The data depicted in (Table 4) revealed that Silymarin, very high significantly counteracted the undue effect of $\mathrm{CCl} 4$ in all the recorded parameters. It may be pointed out that almost always the two EA test extract displayed similar findings .The data also revealed in general that silymarin exerted more potency with respect to the relative hepatoprotective effect than those recorded by $125 \mathrm{mg}$ and $250 \mathrm{mg} / \mathrm{kg}$ b.w of EA. As can be seen from (the same table) silymarin induced significant decrease in cholesterol concentration than both those indicated by of the two test extract. Also silymarin caused high significant decrease in the level of ALT than those displayed by the two test extracts. In addition, T.G was highly significant low in silymarin than those indicated only by 125 dose level of EA. Moreover, silymarin induced very high significant improvement in the level of AST, ALP, total bilirubin as well as direct and indirect bilirubin together with GSH, GST, than those indicated by $125 \mathrm{mg}$ and $250 \mathrm{mg}$ EA groups. The improvement in the level of protein oxidations as reflected by PC was much less than those recorded after silymarin administration in the group of animals receiving $125 \mathrm{mg}$ EA extract. It may be pointed out that the two test extracts induced similar efficiency to those indicated by silymarin receiving group with respect the antioxidant parameters (MDA, SOD, and GPX) as well T.P and Alb. The data shown in Table 4 proved that the two extract displayed almost identical effect with respect to their antioxidant activity (MDA, SOD, GSH, GPX and GST) in addition to the serum level of T.P and Alb. The dose response effect of EA extract was clearly indicated with respect to the very high significant improvement indicated after $250 \mathrm{mg} / \mathrm{kg}$ dose of EA than those recorded after $125 \mathrm{mg}$ EA extract with respect to cholesterol, T.G, ALT, AST, ALP and oxidative protein level. The level of total bilirubin as well as direct and indirect bilirubin was significantly improved after $250 \mathrm{mg}$ EA administration above those indicated after $125 \mathrm{mg}$ EA ingestion.

The data shown in (Table 5) displayed the \% changes indicated due to the protective effect of silymarin, $125 \mathrm{mg} \& 250 \mathrm{mg}$ EA extracts/ $\mathrm{kg}$ b.w and assessed their efficiency is counteracting the detoxification and hazards displayed by $\mathrm{CCl} 4$ in both liver function and antioxidative stress. The data revealed that silymarin in the dose $25 \mathrm{mg} / \mathrm{kg} \mathrm{b} . \mathrm{w}$ was more potent that the two test doses of EA. The recorded \% changes of silymarin were ranging between $12.5 \%$ improvement in serum albumin level and $31.5 \%$ for both cholesterol \& triglycerides. In the mean time, $250 \mathrm{mg}$ EA dose was more potent than $125 \mathrm{mg}$ EA dose with respect to cholesterol, triglycerides \& the three liver enzymes in addition to PC. It may be noted that the two test doses exerted almost equivalent improvement against $\mathrm{CCl} 4$ side effect with respect to total, direct and indirect bilirubin, total protein and all the antioxidant parameters. 
Table 4: In vivo changes indicated in serum biochemical parameters after 4 weeks simultaneous administration of each of silymarin and the two test doses of EA arial parts aqueous extract and $\mathrm{CCl} 4$ induced hepatotoxicity in rats.

\begin{tabular}{|c|c|c|c|c|c|}
\hline Item & Units & $\begin{array}{c}\text { CCL4 } \\
(\text { Mean } \pm \text { SE })\end{array}$ & $\begin{array}{l}\text { CCL4- Silymarin } \\
(\text { Mean } \pm \text { SE) }\end{array}$ & $\begin{array}{l}\text { CCL4- EA } 125 \\
(\text { Mean } \pm \text { SE) }\end{array}$ & $\begin{array}{l}\text { CCL- EA 250 } \\
(\text { Mean } \pm \text { SE })\end{array}$ \\
\hline Cholesterol (Chol.) & $m g / d l$ & $175.1 \pm 2.4$ & $120.2 \pm 1.2^{k x}$ & $150.6 \pm 2.1^{* 2 *} A$ & $137.3^{ \pm 1.2}{ }^{* * *} \mathrm{Am}$ \\
\hline Triacylglycerol (TG) & $m g / d l$ & $750.5 \pm 3.2$ & $470.3 \pm 2.1$ & $685.9 \pm 5.1 \quad B$ & $570 . \pm 4.5^{* * *} \mathrm{Cm}$ \\
\hline Alanine Transaminase (ALT) & $U / L$ & $160.1 \pm 1.7$ & $85.5 \pm 2.4 \mathrm{C}^{* * 1}$ & $150.4 \pm 1.6^{* * *} B$ & $105.5 \pm 2.3^{* * \pi} B m$ \\
\hline Aspartate Transaminase (AST) & $U / L$ & $335.1 \pm 1.3$ & $170.5 \pm 1.3$ & $295.2 \pm 1.6{ }^{* * *} C$ & $240.5 \pm 3.2 \quad \mathrm{Cm}$ \\
\hline Alkaline phosphatase ( ALP) & $U / L$ & $1005.0 \pm 8.6$ & $405.5 \pm 2.5$ & $895.6 \pm 7.2{ }^{* * x} C$ & $701.2 \pm 5.1{ }^{* * *} \mathrm{Cm}$ \\
\hline Total bilirubin (T.Bil) & $m g / d l$ & $8.1 \pm 0.2$ & $2.70 \pm 0.1$ & $3.50 \pm 1.7{ }^{* * t} C$ & $2.74 \pm 0.4{ }^{* * *} C k$ \\
\hline Direct bilirubin ( D.Bil) & $m g / d l$ & $2.40 \pm 0.7$ & $0.41 \pm 0.1$ & $0.83 \pm 0.2^{* * *} C$ & $0.74 \pm 0.3^{* * *} C k$ \\
\hline Indirect bilirubin ( I.Bil) & $m g / d l$ & $5.7 \pm 0.5$ & $2.29 \pm 0.03$ & $2.67 \pm 0.7 C$ & $2.85 \pm 0.2 C k$ \\
\hline Total proteins ( T.P) & $g / L$ & $5.40 \pm 0.6$ & $7 \cdot 90 \pm 0.12$ & $7.97 \pm 0.4$ & $7.93 \pm 0.11$ \\
\hline Albumin (Alb) & $g / L$ & $2.20 \pm 0.35$ & $4.95 \pm 0.20$ & $4.98 \pm 0.30$ & $4.96 \pm 0.23^{*}$ \\
\hline Malondhyde (MDA) & U mol/g protei & $0.87 \pm 0.82$ & $0.50 \pm 0.32$ & $0.49 \pm 0.51$ & $0.48 \pm 0.902^{*}$ \\
\hline Superoxide anion radical (SOD) & $u / m g$ protein & $2.75 \pm 0.06$ & $4.01 \pm 0.12^{* * * *}$ & $3 \cdot 99 \pm 0.13^{* * * *}$ & $3.98 \pm 0.11^{* * 4}$ \\
\hline Glutathione (GSH) & $\mathrm{mg} / \mathrm{g}$ tissue & $1.06 \pm 0.05$ & $1.71 \pm 0.03$ & $1.60 \pm 0.05{ }^{* * *} C$ & $1.55 \pm 0.03^{* *} \mathrm{C}$ \\
\hline Glutathione peroxidase (GPX) & $u / m g$ protein & $4.12 \pm 0.05$ & $5.85 \pm 0.2$ & $5 \cdot 90 \pm 0.12$ & $5.80 \pm 0.10$ \\
\hline Glutathione Transferase (GST) & $u / m g$ protein & $5.00 \pm 0.07$ & $5.92 \pm 0.13$ & $5.30 \pm 0.11{ }^{*} C$ & $5.20 \pm 0.12^{*} \mathrm{C}$ \\
\hline Carbonyl proteins $(P C)$ & U mol/mg Prol & $2.52 \pm 0.03$ & $1.79 \pm 0.03$ & $2.30 \pm 0.02 \mathrm{C}^{* * \pi} \mathrm{C}$ & $2.10 \pm 0.04^{* * x} \mathrm{~m}$ \\
\hline
\end{tabular}

* Significant, ** High Significant and $* * *$ Very high Significant at $\mathrm{p}<0.05, \mathrm{p}<0.01$ and $<0.001$ from CCl4. A: Significant, B: H. Significant and C: V.H. Significant between CCL4 and Silymarin group.

K: Significant, 1: H. Significant and m: V.H. Significant between the EA 250 and EA 125 group. 
Table 5: Relative \% of changes indicated in the test groups as compared to $\mathrm{CCl} 4$ intoxicated group.

\begin{tabular}{|c|c|c|c|c|}
\hline Item & $\mathrm{CCL}_{4}-\mathrm{Sil}$ & $\operatorname{tarin} \%$ & CCL- EA 250\% & CCL4-EA $125 \%$ \\
\hline Cholesterol (Chol.) & 31.5 & 凸 & $21.7^{* 2 \times 4}$ & $14 \cdot 3^{* * *}$ 口 \\
\hline Triacylglycerol (TG) & $31.4^{* * \pi}$ & 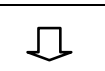 & $34^{* * *}$ 口 & $8.7^{*} \square$ \\
\hline Alanine Transaminase (ALT) & $46.7^{* * *}$ & 几 & $34.2^{* * *} \Omega$ & $6.4^{*}$ 几 \\
\hline Aspartate Transaminase (AST) & $49.2^{* * *}$ & $\square$ & $29 \cdot 3^{* * *} \square$ & $21.9^{* * * *} \square$ \\
\hline Alkaline phosphatase ( ALP) & $59 \cdot 7^{* * *}$ & 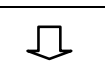 & $30.3^{* * *}$ 几 & $18.9^{* *}$ 口 \\
\hline Total bilirubin ( T.Bil) & $65.7^{* * * *}$ & 几 & $65.2^{* * *}$ 几 & $65.8^{* * *}$ 几 \\
\hline Direct bilirubin ( D.Bil) & $82.9^{* * *}$ & П & $69.2^{* * * *} \square$ & $65.4^{* * *}$ 几 \\
\hline Indirect bilirubin ( I.Bil) & $59 \cdot 9^{* * * x}$ & $\square$ & $50 \quad \square$ & $54.2^{* * *}$ 几 \\
\hline Total proteins ( T.P) & $46.2^{* * *}$ & $\square$ & 46.8 几 & $47 \cdot 5^{* * * *}$ 几 \\
\hline Albumin (Alb) & $125^{* * *}$ & $\widehat{\imath}$ & 125.4 亿 & $126^{* * *}$ 亿 \\
\hline Malondhyde (MDA) & $42.6^{* * *}$ & 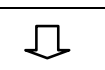 & $45^{* * * *}$ 几 & $43.7^{* * *} \square$ \\
\hline Superoxide anion radical (SOD) & $45.8^{* * *}$ & $\widehat{\iota}$ & 44.7 仓 & $45.1^{* * *}$ 厄 \\
\hline Glutathione (GSH) & $61^{* * *}$ & 厄 & 46.2 ૫ & $49.1^{* * *}$ 亿 \\
\hline Glutathione peroxidase (GPX) & $41^{* * *}$ & $\widehat{\imath}$ & $40^{* * *}$ 凹 & $43^{* * \hbar}$ \\
\hline Glutathione Transferase (GST) & $18.4^{* *}$ & 厄 & 4 亿 & $6 *$ \\
\hline Carbonyl proteins (PC) & $29^{* *}$ & $\square$ & $102^{* * *}$ 几 & $41.7^{* * * *}$ 几 \\
\hline
\end{tabular}

*Significant, $* *$ High Significant and $* * *$ Very high Significant at $\mathrm{p}<0.05, \mathrm{p}<0.01$ and $<0.001$ from $\mathrm{CCl} 4$. 


\section{DISCUSSION}

Attention were bayed in National Organization for Drug Control and Research (NODCAR) for cultivation and acclimatization of several herbs and herbal products that are known to possess antioxidant principles and may be useful as organ protective agents among of which herbs belonging to Euphorbiaceae, were reported to have antioxidant principles and organ protective properties (Lanthers et al., 1991 and Trease and Evans, 2001).

Euphorbia antiquorum family are small trees rowing throughout the hotter parts of the world, and as herbal drugs, containing antiradicals constituents, are now gaining importance in prevention and treatment of oxidative stress linked diseases (Akihisa et al., 2005).

In the meantime, preliminary phytochemical investigation reported in the present study showed the presence of triterpenes \& flavonoids, both of which were previously reported to possess antioxidant, hepatoprotective, activity (Fauconneau et al., 1997 and Sunitha $\boldsymbol{e t}$ al., 2001) may be provided as a modern medicine for treatment of liver diseases.

It may be pointed out that oral acute toxicity screening test proved that $5000 \mathrm{mg} / \mathrm{kg}$ oral dose was safe. This finding runs parallel with Jyothi et al., (2007) who reported that none of the test albino rats died at $2500 \mathrm{mg} / \mathrm{kg}$ dose.

As can be seen from the in virto results in the present study, the reducing power of EA extract may serve as a significant indicator of its potential antioxidant activity. Table 1: illustrated that the different doses of EA extract exhibited a remarkable reducing potency to donate electron to stabilize the reactive free radical and reduce the oxidized intermediates in concentration dependant as compared to SMS as a reference agent in PMS-NaOH system and reduced the oxidized intermediates. Meanwhile, the reducing and inhibition capacity of EA $(100 \mathrm{ug} / \mathrm{ml})$ was similar to SMS effect in PMS-NaOH system due to the dose dependant increase in the amount of absorbance and the reducing capacity indicating that the EA possesses increased dose dependant reducing power (Salma et al., 2004) .

It may pointed out that results in (Table 2 ) illustrated that the increase of the inhibition properties by the degradation of 2- deoxyribose in phenylhydrazine solution (Sasanka et al., 1990), revealed that all different doses of EA extract, generated different concentrations of $\mathrm{OH}$ radicals. Meanwhile, the inhibition capacities of $\mathrm{OH}$ radicals in EA were similar to SMS effect of hydroxyl radical scavenging activity in the solution system due to the dose dependant increase in the inhibition values. The obtained results in the current study agreed with those previously indicated by Jyothi et al., (2007).

In the present study in virto antioxidant activities displayed significant increase in the reducing power absorption that was coupled with reductions in hydroxyl ion absorption and superoxide anion scavenging activities. These results revealed that EA extract only reduced and not interfere with the generation the superoxide anion (i.e) scavenging off the $\mathrm{OH}$ radical and hence inhibit cell damage that may occur as a result of the reaction between superoxide radicals and $\mathrm{H} 2 \mathrm{O} 2$ (Treas and Evans, 2001. It is also known that $\mathrm{OH}$ radicals can attack the sugar of DNA base causing sugar fragmentation, base lose and DNA strand leakage (Sasanka et al., 1990).

The results obtained by the in vitro study clearly assessed the successful acclimatization of EA in National Organization for Drug Control and Research (NODCAR) farm and demonstrated the incidence of dose dependent antioxidant activity by the aqueous extract. This finding was convenient to proceed with the in vivo hepatoprotective effect of the test extract against CCL4 intoxication. 
As can be seen from the data in (Table 3) four weeks CCL4 intoxication caused well marked disturbances in the test biochemical parameters. The hepatotoxicity effects are largely due to $\mathrm{CCl} 4$ biotransformation by the cytochrome $\mathrm{P}-450$ system to active metabolite, trichloromethyl radical (Recknagel et al., 1989). Covalent binding of the trichloromethyl radical to cell protein is considered the initial step in a chain of events that eventually leads to lipid peroxidation of the cell membrane and endoplasmic reticulum. Lipid peroxidation in turn gives products like malondialdehyde (MDA) that cause damage to the membrane. The peroxidative products induce hypoperfusion of the membrane and finally cytosolic enzymes appear in the blood (Recknagel et al., 1989). The data reported in table 3 revealed that this could be the reason where the levels of marker enzymes AST, ALT and ALP were found to be elevated. This point of view was previously assessed by the studies reported by Kwak et al. (1993) and Hewawasam et al. (2003).

The very highly significant elevations in T.G that was coupled with highly and very highly significant reduction in the level of serum $\mathrm{T}$. proteins and albumin could be referred to the fact that the toxicity produced by $\mathrm{CCl} 4$ may be also due to the reaction of free radicals $\mathrm{CCl} 3$ or $\mathrm{CCl} 3 \mathrm{COO}$ with lipids and proteins (Cameron and Karunarathe, 1936 and Yick et al., 1993).

Meanwhile, the reduction in total proteins may be attributed to the damage produced and localized in the endoplasmic reticulum leading to decrease in protein synthesis (Kancha and Sadiq, 2010).

Also Recknagel et al. (1989), Gergely et al. (1995) and Dannenberg (2001) reported that in case of $\mathrm{CCl} 4$ induced hepatotoxicity, $\mathrm{CCl} 4$ was converted into $\mathrm{CCl}^{-} \mathrm{O}^{-}$by liver enzymes and attacks the unsaturated fatty acids of cell membrane in presence of oxygen which consequently gives rise to lipid peroxides (MDA) which alters the functional integrity of liver mitochondria leading to liver damage. The hepatotoxic effect of $\mathrm{CCl} 4$ was also markedly indicated by the very high significant increase of serum cholesterol. The \% increase recorded reached 59\% above those recorded by normal healthy rats. The magnitude of CCl4 intoxication reached its maximum effect in case of total bilirubin, direct bilirubin and indirect bilirubin where the \% increased in their level reached $852 \%, 827 \%$ and $863 \%$ respectively.

It may be pointed out that hyperbilirubinemia (Table3) was most frequently indicated in advanced chronic liver diseases and can be deemed as a useful index of the severity of cellular dysfunction. Both total and direct bilirubin levels rise in disease of hepatocytes, obstruction to biliary excretion into duodenum, hemolysis, in defects of hepatic uptake and conjugation of bilirubin pigment such as in Gilbert's disease. Hyperbilirubinemia results from impaired hepatic uptake of unconjugated bilirubin in liver cell injury (Recknagel et al. 1989). In the current study and as shown in hyperbilirubinemia observed in CCl4 intoxicated rats may be attributed to the excessive heme destruction and blockage of the biliary tract where there is a mass inhibition of conjugation reaction and release of unconjugated bilirubin from damage hepatocytes (Tiez, 1995).

The in vivo study (Table 3) pointed out that the marked depletion in the level of antioxidant enzymes activities observed after ingestion of CCL4 for 4 weeks is a clear manifestation of inactivation or failure of antioxidant enzymes to scavenge the excessive formation of free radicals resulting in accumulation of free radicals redox in balance which in turn propagates the oxidative stress and liver injury (Gill and tuteja, 2010).

The current results confirmed that the hepatic antioxidant defense system was significantly increased in the treated groups for 4 weeks indicate their safety profile. However, the data depicted in (Table 4) demonstrated that a CCL4 treated for 4 weeks was associated with 
very high significant impairment of the hepatic antioxidant defense system (GSH, GPX and GST) as regarded to normal control group, while, the groups of animals pretreated with EA extract or silymarin for 4 weeks exhibited active antioxidant capacity, this improvement was in the order of silymarin < EA $250<$ EA 125.

The interrelationship between the test antioxidant parameters were previously described by Ayka et al. (1985) and Rotruck et al. (1973) who reported that glutathione (GSH) plays an important role in the removal of free radical species through glutathione peroxidase (GPX), glutathione Transferase (GST) and glutathione reductase (GSR) activities and maintenance of membrane of protein thiol. The results of current study supported the view that the decreased intracellular pool of GSH after ingestion of CCL4 $(1 \mathrm{mg} / \mathrm{kg} / \mathrm{b} . \mathrm{w})$ for 4 weeks resulted in inadequate detoxification mechanism and failure of antioxidant defense mechanisms to prevent the formation of excessive accumulation of highly toxic metabolites and free radicals .

The marked elevations in PC contents after 4 weeks ingestion suggest excessive protein oxidation. It may be pointed out that proteins oxidation is defined as the covalent modification of a protein induced either directly by reactive oxygen spices (ROS) or indirectly by reaction with the byproducts of oxidative stress (Gill and Tuteja, 2010). Oxidative modifications of protein alter their biological properties, leading to their fragmentation, increased cross linking aggregation and enzyme dysfunction (Gracanin et al., 2009). The protein carbonyl derivatives (PC) are chemically stable and result of oxidative cleavage of the protein backbone, direct oxidation of amino acids such as lysine, arginine, histadine, proline, glutamic acid and thereonin by binding of aldhyde produced from lipid peroxidation (Basle $\boldsymbol{e t}$ al., 2010), therefore, the assay of carbonyl proteins (PC) provide a covalent technique for detecting and quantifies the oxidative modification of proteins.

It may be pointed out that the results in the current study revealed that the pretreated groups with EA extracts were able to inhibit the oxidative modification of liver proteins (T.P and Alb). The beneficial effects of the two tests extract can be attributed to antioxidant activity of the bioactive constituents of tested extracts of EA.

The data reported by Kapur et al. (1994), Jyothi et al. (2008) and Pal and Manoj (2011) revealed that short lasting pretreatment of EA extracts that was followed by CCl4, exhibited less damage to the hepatic cells as compared to the rats treated with $\mathrm{CCl} 4$ alone. They added that this finding was an indication of stabilization of plasma membrane thereby preserving the structural integrity of cell as well as repairing and regenerating of hepatic tissue damage that was caused by co- administration of CCL4 .The data recorded in the current study revealed that EA extract $(125 \mathrm{mg}, 250 \mathrm{mg} / \mathrm{kg} . \mathrm{b} . \mathrm{w})$ was also efficient in assessing the previous finding after simultaneous co-administration with $\mathrm{CCl} 4$ for 4 weeks as they caused very high significant decrease in the three test enzymes. The data also revealed that EA $250 \mathrm{mg} / \mathrm{kg} \mathrm{b} . \mathrm{w}$ was more potent than EA $125 \mathrm{mg} / \mathrm{kg}$ b.w.

The two test extracts also counteracting the reduction indicated by $\mathrm{CCl} 4$ in the level of total protein and albumin which suggest that EA extract stop the damage produced and localized in the endoplasmic reticulum. These findings also assess the stabilizing effect of these extract on cell liver integrity.

The protection of the two test extracts of protein synthesis against $\mathrm{CCl} 4$ protein oxidative modification (PC) seemed to be less potent than those indicated by $25 \mathrm{mg} / \mathrm{kg}$ b.w oral silymarin. It may be pointed out that the two test extracts were as potent as silymarin against elevation of lipid peroxidation as evidenced by equivalent very high significant reduction in MDA level. It may be also indicated that both silymarin as well as the two test extracts share 
each other in a common mechanism that cause improvement in the test serum biochemical parameters.

The data also revealed that silymarin as well as the two test extracts counteracted the very high significant elevations indicated in total as well as direct and indirect bilirubin; these data could be considered as an encouraging indication for the use of this plant in jaundice remedy and offering liver protection. The recorded data confirmed the hepatic antioxidant defense against $\mathrm{CCl} 4$ intoxication by silymarin as well as the two test extracts.

It was of interest to indicate that the two test extracts were as potent as silymarin in their antioxidant efficiency. A fact that strongly encourage the use of EA extract for antioxidant medication. Moreover, the equipotent antioxidant effect of $125 \mathrm{mg} / \mathrm{kg} \mathrm{b.w} \mathrm{EA} \mathrm{and} \mathrm{those}$ indicated by $250 \mathrm{mg} / \mathrm{kg}$ b.w also suggest that EA may excrete high antioxidant properties by using lower dose.

In conclusion it may be indicated that local acclimatization of EA plant in Egypt did not decrease its hepatoprotective and antioxidant potency. Meanwhile, the EA extract seemed to be more potent as antioxidant rather than hepatoprotection. The hepatoprotection activity of EA still required more investigations to support the traditional use of EA as an herbal remedy for jaundice and other liver disorders, and to assess the feasibility of development of herbal formulation for clinical studies.

\section{Acknowledgments:}

I am most gratitude to the staff member of phytochemical analysis department in Applied Research of Medicinal Plants (ARCMP) in National Organization for Drug Control and Research (NODCAR) for their valuable suggestions and advices at different stages in this investigation. Thanks are extended to Dr .Gouda M.T researcher of phytochemical department for his help in supply of authentic sample of the plant material.

\section{REFERENCES}

Allain, C.C.; Poon, L.S.; Chan, C.S.G.; Richmond, W. and Fuci, P.C. (1974): An enzymatic method for determination of total cholesterol.Clin.Chem.20:470-475.

Aykae, G., M.; Vysal, A.S.; Yalein, N. Kocak-T. A. and Hofer, O.Z. (1985): The effect of chronic ethanol ingestion on hepatic lipid peroxide, glutathione, glutathione peroxidase and glutathione transferase in rats. Toxicology. 36: 71-76.

Akihisa Wijeratne, T. E.M.; Tokuda, H. ; Enjo, F. and Torium, M. . Kimura, Y.; Koike, K.; Nikaido, T.; Tezua, Y. and Nishino, H. (2005): Eupha-7, 9 (11), 24-trien-3 beta-ol (Antiquol C) and other Triterpenes from Euphorbia antiquorum latex and their inhibitory effects on Epstein-Barr virus activation. J Nat Prod. 65 (2): 158-16.

Basle, E.; Joubert, N. and Pucheault, M. (2010): Protein chemical modification on endogenous amino acids .Chemistry and Biology: 17: 713- 727.

Barry Hathwell and John gutteridge M. (1981): Formation of a thiobarbituric acid reactive substance from deoxyribose in the presence of Iron salts. FEBS letters, vol. 128, No.2: 347- 352.

Buege, J.A and Aust, S.D (1978): The potential toxic effect of paracetamol overdose, microsomal lipid peroxidation Methods Enzymol; 52, 302- 310. 
Cameron, GR and Karunarathe, WAE (1936): The pathogenesis of liver injury in carbon tetrachloride and thioacetamide poisoning. J. Pathol. Bacteriology. 81: 107-117. Methods (oral). Arch. Toxicol. 69: 729-734.

Chrungoo, V. J.; Kuldip, S. and Jaswant, S. (1997): Differential biochemical response of freshly isolated rat hepatocytes to paracetamol, carbon tetrachloride and galactosamine toxicity. Indian J Exp Bio. 35: 603-610.

Dannenberg, A.J. (2001): Increased severity of alcoholic liver injury in female rats: role of oxidative stress, endotoxin and chemokines. Am. J. Physiol. Gastrointest. Liver Physiol. 281: 1348-1356.

Domus, B.T. (1975): Standard for total serum protein assay -A collaborative study. Clin.chem; 21:1159-1166.

Domus, B.T.; Watson W.A. and Biggs, H.G. (1971): Albumin standard and the measurement of serum albumin with bromocresol green. Clin. Chem, Acta 31:87-96.

Fauconneau, B.; Waaffo-Tequo, F.; Hugnet, F.; Barries, I.; Decendit, A. and Merillon, J.M. (1997): Comparative study of radical scavenger and antioxidant properties of phenolic compounds from Vitas vinfera cell culture using in vitro tests. Life Sciences. 16: 2103-2110.

Fossati, p., and Prencipe L. (1982): A colorimetric method for determination of hydrogen peroxide.Clin.Chem.28:2077-2080.

Gergely, J.; Kulcsar, A. and Harsfalvi, J. (1995): Changes in fat metabolism in acute carbon tetrachloride intoxication of rats. Acta. Pharm. Hung. 65(1): 3-4

Gill, S.S. and Tuteja, N. (2010): reactive oxygen species and antioxidant machinery in a biotic stress tolerance in crop plants .plant physiology and biochemistry; 48:902: 920.

Gracanin, M.; Hawkins, CL.; Pattison, D.I. and Davies, M.J. (2009): Single - oxygen mediated amino acid and protein oxidation formation of tryptophan peroxides and decomposition product. Free Rad.Biol.Med; 47:92: 102.

Habig, WH.; Paspat, MJ. and Jak0by, WB. (1974): Glutathione S Transferase the first enzymatic step in mercapturic acid formation .J Bioll Chem. 249; 7130-7139.

Hewawasam, RP. ; Jayatilaka, K.; Pathirana, C. and Mudduwa, L. (2003): Protective effect of Asteracantha longifolia extract in mouse liver injury induced by carbon tetrachloride and paracetamol. J.Pharm. Pharmacol. 55: 1413-1418.

Jayasri, MA. ; Mathew, K. and Radha, A. (2009): A report on the antioxidant activities of Leaves and rhizomes of Costus D.Don. Inter . J. Integer Bio. 5: 1-20

Jyothi, TM. ; Prabhu, K.; Jayachandran, E.; Lakshminarasu, S.; Ram Chandra, and Setty, S. (2007): Hepatoprotective and antioxidant activity of Euphorbia antiquorum. India. J. Pharmcognosy. Magazine Vol-4, issue 13. (Supp-1) 973-1296.

Jyothi, TM. ; Shankariah, MM.; Prabhu, K.; Lakshminarasu, S. ; Shinivasa, GM, and Ramachandra, S.S (2008): Hepatoprotective and antioxidant activity of Euphorbia antiquorum. Iran. J. Pharmcol. Ther. 7: 25-30. 
Johan, D. and Bauer, T. (1982). An enzymatic method for determination alkaline phosphatase. 9 Th Ed. 580: 581.

Kanchana, N. and Sadiq, AM. (2010): Hepatoprotective effect of plumbago zeylamica on paracetamol induced liver toxicity in rats. International $\mathbf{J}$ of pharmaceutical Science 3(1)151-154.

Kapur, V.; Pillai, KK. ; Hussian, SZ. and Balani DK (1994): Hepatoprotective activity of "JIGRINE" a polyherbal formulation against liver damage caused by alcohol-carbon tetrachloride and paracetamol in rats. Ind. $\mathrm{J}$ of pharmacology, 26:35-40.

Kirtikar, K.R. and Basu, B.D. (1975): Indian medicinal plants, vol3, (M/s Bishen singh Mahendrapal singh, Dehardun,) pp.2204.

Kwak, M.K.; Kim, .G. J.Y.; Novak. R.F. and Kim, N.D. (1993): inhibition of cytochrome p 450 expression of organosulfer compounds ally sulfide, allymerctane and allymethyl sulfide in rats Bio-Chem. Pharmacol. 47: 531-9.

Lanthers, M.C.; Fleurentin, J.; Dorfman, P.; Mortier, F. and Pelt, J.M. (1991): Analgesics', antipyretic and anti- inflammatory properties of Euphorbia hirta. Planta Med. 57(3): 225-231.

Levin, RL. ; Garland, D.; Oliver, CN. ; Amici, A.; Climent, I.; Lenz, AG. Ahn, BW. ; Sholtiel, S. and Stadtman, ER. (1990): Determination of carbonyl content in oxidatively mediated proteins. Methods Enzymol; 186: 464.

Macdonlad, S.; Prenzler, PD.; Antolovich, M. and Robrats, K. (2001): Phenolic content and antioxidant activity of live extracts. Food Chemistry. 73: 73-84.

Marklund, S, and Marklund, G, (1974): Involvement of the superoxide anion radical in the autoxidation of pyrogallol and conventient assay for superoxide dismutase. Eurp .J. Biochem. 17: 169-74.

Merrill, W.L. (1977): An Investigation of Ethnographic and Archaeological Specimens of Mescalbeans (Sophora secundiflora). Anthropology, 22:235-260.

Nishimiki, M.; Rao, N.A. and Vagi, K. (1972): The occurrence of superoxide anion in the reaction of reduced Phenazine methosulphate and molecular oxygen. Biochemical \& Biophysical Res Com. 46: 489-453.

Organization for Economic Co-operation and Development (OECD, 1996): Guidelines for the testing of chemicals. Test no 423: Acute Oral toxicity -Acute Toxic Class Methode .paris: Organization for Economic C0-operation and Development.

Oyaizu, M. (1986): Studies on product of browning reaction preparation from glucose amine. Japaneese J of Nutrition. 44: 307-310.

Pal, RK. and Manoj, J.(2011): Hepatoprotective activity of alcoholic and aqueous extracts of APEA linn in rats . Annals of biological Research; 2(1):132-141.

Recknagel, RO.; Glende, Jr.; EA, Dolak, JA. and Waller, RL. (1989): Mechanism of carbon tetrachloride toxicity. Pharmacology. 43: 139-145. 
Retiman, S. and Frankel, S. (1957): A colorimetric method for determination of serum glutamic-oxaloacetic and glutamic-pyruvic transaminases. Am.J. Clin. Pathol. 28: 56-63.Company, USA, pp. 393-440.

Rotruck, JT.; Pope, AL, ; Ganther, H. ; Swanson, AB. ; Hafeman, DG. and Hoekstra, WG. (1973): Selenium Biochemical role as a component of glutathione peroxidase .Science. ; 179:588-590.

Salma, K.; Shivprasad, HN. and Kshana, D. (2004): In vitro Antioxidant screening models: A review. Indian J. pharm. Educ. 38(4):180-183.

Saleem, M.T.S.; Chetty, C.M.; Ramkanth, S.; Rajan, V.S.; Kumar, K.A. and Mand G. (2010): Hepatoprotective herbs: A review Int.J.Res.Pharm. Sci.; 1:1-5

Sasanka, S.; Asha, N., and Gali R. (1990): Phenylhydrazn in mediated degradation of Bovine serum albumin and membrane proteins of human erythrocytes.Biochem ET Biophys Acta. 1028: 89-94.

Sholtiel, S. and Stadtman, ER. (1990): Determination of carbamyl content in oxidatively mediated proteins .methods Enzymol; 186: 464.

Snedicor, G.W. and Cochran, W.G. (1967): In statistical methods, 6 Th edn., Lowy state university, Press, Ames 1 A.; p.104.

Sunitha, S., M.; Nagaraj, A.N. and Varalakshmi, P. (2001): Hepatoprotective effect of lupeol and lupeol linoleate on tissue antioxidant defense system in cadmium-induced hepatotoxicity in rats. Fitoterapia.72: 516-523.

Tietze, $N, M$ (1968): A colorimetric method for determination serum bilirubin. Text book of Clin Chem. P 1389-1390.

Tietze, F. (1986): Enzymic method for quantitative determination of nanogram amounts of total and oxidized glutathione: applications to mammalian blood and other tissues. Anal. Biochem. 27(3): 502-522.

Tiez (1995): Total bilirubin in: Clinical Guide to laboratory tests 3 rd: PP 384-385, WB Sounders Press, and Philadelphia.

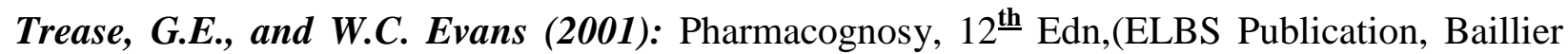
Tindall, East Bourne,) pp. 495.

Vaidyaratnam, P.S. and Vaidyasala V. A. (1995): Indian Medicinal Plants, (Orient Longam Ltd, Chennai,) pp.388.

Yick, T.W.; Chiu, Hui T.Y.; Cheng, C.H.K. and Kong Y.C. (1993): Impaired antioxidant status I in CCl4 intoxicated rats: an in vivo study. Fitotherapia.LXIV: 539- 544.

Zou, Y. LU. Y. and Wei, D. (2004): Antioxidant activity of a flavonoid-rich extract of Hypericium perforatum L vitro. Journal of agriculture Food Chemistry, 52(16): 5032-5039. 


\title{
دراسده مختبريه وحيويه على كفاءة الثوله البيضاء كمضاد للأكسدة فى الحفاظ على الكبد و الوقايه ضد مخاطر رابع كلوريد الكربون في كبد الفئران
}

\author{
منصور حامد محمد \\ مدير مركز الدراسات التطبيقيه لبحوث النباتات الطبيه ورئيس شعبة المضادات الحيويه
}

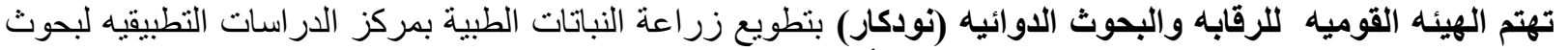

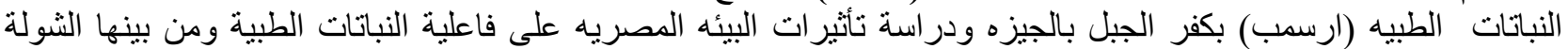

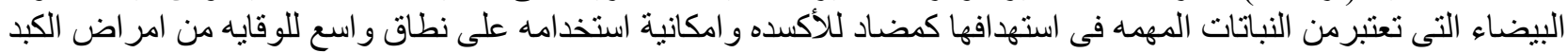

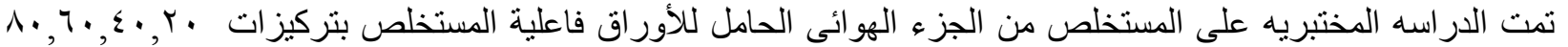

حتى . . 1 ميكروجم / ملم كمضاد للاكسده حيث اختزل القوه الهيدروكسيليه و انيون الهيدروكسيل و النشاط الكاسح لانيون

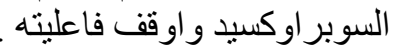

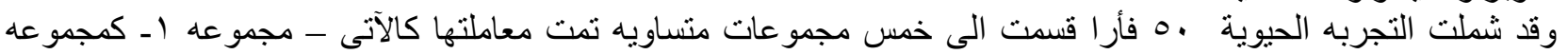

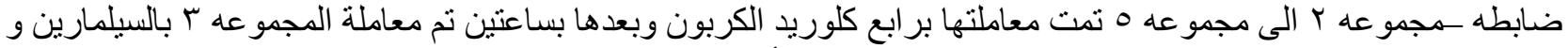

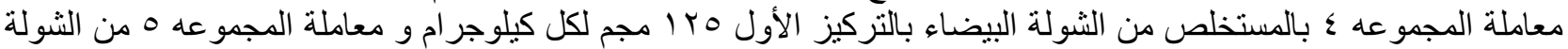

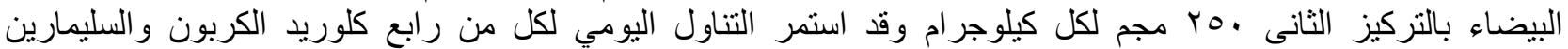

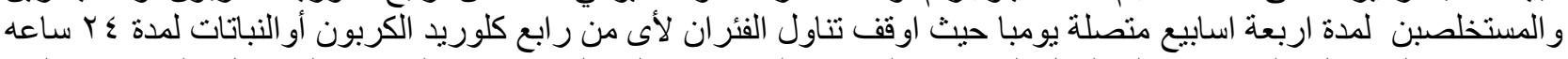

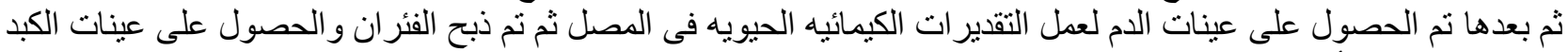

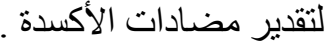

وقد اظهرت النتائج ما يلى : احدث استخدام رابع كلوريد الكربون بالمجمو عه الثانيه اصابه لكبد الفئر ان على شكل ارتفاعات

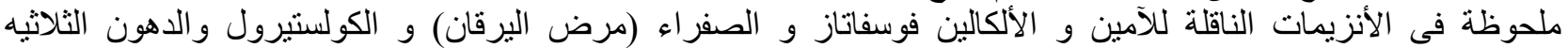

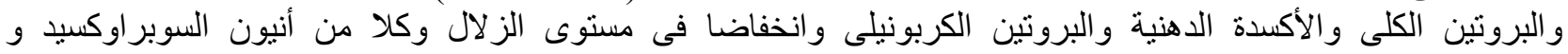

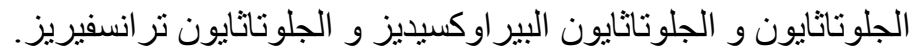

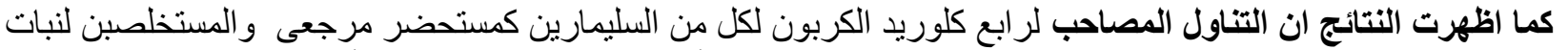

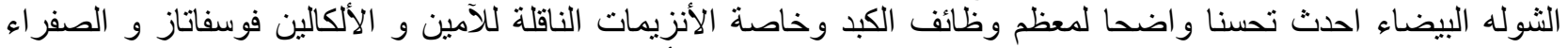

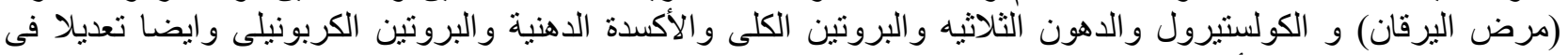

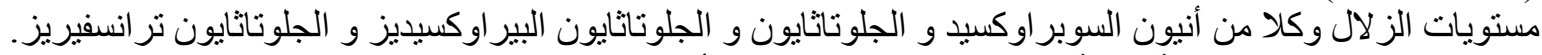

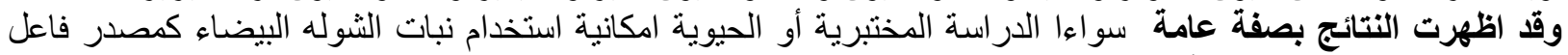

